\title{
EPIDEMIOLOGY OF PRIMARY AND SECONDARY HEADACHES IN A BRAZILIAN TERTIARY-CARE CENTER
}

\author{
André Carvalho Felício, Denis Bernardi Bichuetti, William Adolfo Celso dos Santos, \\ Clecio de Oliveira Godeiro Junior, Luis Fabiano Marin, Deusvenir de Souza Carvalho
}

\begin{abstract}
Objective: To analyze the demographic features of the population sample, the time of headache complaint until first consultation and the diagnosis of primary and secondary headaches. Method: 3328 patients were analyzed re trospectively and divided according to gender, age, race, school instruction, onset of headache until first consultation and diagnosis(ICHD-II, 2004). Results: Sex ratio (Female/Male) was $4: 1$, and the mean age was $40.7 \pm 15$ years, without statistical diffe rences between sexes. Approximately $65 \%$ of the patients were white and $55 \%$ had less than eight years of school instruction. Headache complaint until first consultation ranged from 1 to 5 years in $32.99 \%$ patients. The most prevalent diagnosis we re migraine (37.98\%), tension-type headache-TTH (22.65\%) and cluster headache $(2.73 \%)$. Conclusion: There are few data on epidemiological features of headache clinic populations, mainly in developing countries. According to the literature, migraine was more frequent than TTH. It is noteworthy the low school instruction of this sample and time patient spent to seek for specialized attention. Hypnic headache syndrome was seen with an unusual frequency.
\end{abstract}

KEY WORDS: headache, clinic-based study, epidemiology.

\section{Epidemiologia das cefaléias primárias e secundárias em um serviço terciário brasileiro.}

RESUMO - Objetivo: Analisar os aspectos demográficos da população em estudo, o tempo decorrido desde o início da queixa de cefaléia até a busca pelo serviço, assim como o diagnóstico das cefaléias primárias e secundárias. Método: 3328 pacientes foram analisados re trospectivamente de acordo com sexo, idade, raça, escolaridade, tempo decorrido entre o início da cefaléia e a busca ao médico e diagnóstico (ICHD-II, 2004). Resultados: A razão Mulher/Homem foi 4:1, ambos com média de idade 40,7 15 anos, não havendo diferença significativa entre os sexos. Aproximadamente $65 \%$ dos pacientes eram brancos e $55 \%$ tinha menos de 8 anos de escolaridade. A duração da queixa de cefaléia até a primeira consulta foi de 1 a 5 anos em $32,99 \%$ dos pacientes. Os diagnósticos mais prevalentes foram: migrânea (37,98\%), cefaléia do tipo tensional-CTT $(22,65 \%)$ e cefaléia em salvas (2,73\%). Conclusão: Existem poucos dados epidemiológicos de pacientes atendidos em serviços terciários, principalmente em países subdesenvolvidos. De acordo com a literatura, a migrânea foi mais prevalente que a CTT. Também é relevante observar a baixa escolaridade da população, assim como o grande tempo de espera até a primeira consulta. Um número incomum de pacientes com síndrome de cefaléia hípnica foi observado na amostra.

PALAVRAS-CHAVE: cefaléia, clínica terciária, epidemiologia.

Thereare few epidemiological data regarding primary or secondary headaches in clinic-based studies or tertiary-carecenters, mainly in developing countries. Data available is usually from North American or European population-based studies, which are also scant if we consider the economical and social burden of this condition ${ }^{1-17}$.
The aim of this study was to analyze the demographic features of the population sample, the time of headache complaint until first consultation and the diagnosis of primary and secondary headaches according to the ICHD-II (2004) ${ }^{18}$ of adult patients attending a Brazilian tertiary-care center for headache treatment.

Division for Investigation and Treatment of Headaches (DITH), Escola Paulista de Medicina, Federal University of São Paulo (EPM/UNIFESP), Sao Paulo SP, Brazil.

Received 12 July 2005, received in final form 21 September 2005. Accepted 29 October 2005.

Dr. André Carvalho Felício - Avenida Bosque da Saúde 834 / 193 - 04142-081 São Paulo SP - Brasil. E-mail: cf.andre@terra.com.br 
Table 1. Pain duration on the first consultation.

Number of Patients (\%)

\begin{tabular}{lccc}
$\begin{array}{l}\text { Pain } \\
\text { duration }\end{array}$ & $\begin{array}{c}\text { Total } \\
(\mathrm{n}=3297)\end{array}$ & $\begin{array}{c}\text { Female } \\
(\mathrm{n}=2630)\end{array}$ & $\begin{array}{c}\text { Male } \\
(\mathrm{n}=656)\end{array}$ \\
\hline$<1 \mathrm{~m}^{*}$ & 0.87 & 0.60 & 1.98 \\
$1 \mathrm{~m}$ to $11 \mathrm{~m}$ & 14.92 & 13.49 & 20.88 \\
$1 \mathrm{y}^{* *}$ to $5 \mathrm{y}$ & 32.99 & 32.50 & 35.51 \\
$6 \mathrm{y}$ to $10 \mathrm{y}$ & 17.68 & 17.68 & 17.98 \\
$>10 \mathrm{y}$ & 33.48 & 35.73 & 23.65 \\
\hline
\end{tabular}

${ }^{*} \mathrm{~m}$, month; **y, year.

\section{METHOD}

This was a re trospective survey of patient records from January 1999 to May 2004. All patients attended the Division for Investigation and Treatment of Headaches (DITH) from Escola Paulista de Medicina - Federal University of São Paulo. Each record was reviewed and diagnoses were made according to the ICHD-II (2004) ${ }^{18}$. The same headache questionnaire, a standard protocol, was used for each patient. Records with more than two incomplete data were excluded.

Patients were divided according to age, sex (male or female), race (white or non-white), school instruction (none, less than eight years, more than eight years), onset of headache until the first consultation and diagnosis. Symptoms referred on the first appointment, those who lead patient to seek for attention, were considered for diagnosis and classification purposes. Patients with less than 15 years old were excluded from this protocol. Results were recorded as numbers and percentages of patients (descriptive statistics). The study protocol was submitted to and approved by the local ethical committee.

\section{RESULTS}

A total of 3328 patients attended the clinic over the five-year period analyzed. The mean age was 40.7 \pm 15.28 years old without statistical differences between sexes. 3316 were female $(80 \%)$ and the majority of the population was white $(65 \%)$.

Almost $8 \%$ ( $n=246$ patients) had no school instruction, 54\% $(n=1680)$ had less than 8 years and $38 \%$ $(n=1402)$ had more than 8 years. These numbers were similar when comparing both sexes. The majority of patients took 1 year or more to seek for specialized health care and $50 \%$ had suffered for more than 5 years. In general, men attended the DITH later than women (Table 1).
Table 2. Diagnoses According to ICHD-II (2004).

Diagnoses

\begin{tabular}{|c|c|c|c|c|}
\hline IHS code* & $\mathrm{n} * *$ & Female & Male & $\%$ \\
\hline 1 & 1642 & 1576 & 48 & 37.98 \\
\hline 2 & 754 & 590 & 164 & 22.65 \\
\hline 3 & 112 & 49 & 63 & 3.36 \\
\hline 4 & 121 & 93 & 28 & 3.63 \\
\hline 5 & 35 & 17 & 18 & 1.05 \\
\hline 6 & 10 & 4 & 6 & 0.30 \\
\hline 7 & 9 & 7 & 2 & 0.27 \\
\hline 8 & 27 & 17 & 10 & 0.81 \\
\hline 9 & 12 & 8 & 4 & 0.81 \\
\hline 10 & 34 & 26 & 8 & 1.02 \\
\hline 11 & 94 & 69 & 25 & 2.82 \\
\hline 12 & 8 & 6 & 2 & 0.24 \\
\hline 13 & 89 & 70 & 19 & 2.67 \\
\hline 14 & 192 & 105 & 87 & 5.76 \\
\hline
\end{tabular}

*1. Migraine, 2. Tension-type headache, 3. Cluster headache and other trigeminal autonomic cephalalgias, 4. Other primary headaches, 5. Headache attributed to head and/or neck trauma, 6. Cranial or cervical vascular disorder, 7. Non-vascular intracranial disord e $r, 8$. Substance or its withdraw, 9. Infection, 10. Disorder of homeostasis, 11. Disorder of cranium, neck, eyes, ears, nose, sinuses, teeth, mouth or other cranial or facial structures, 12. Pschiatric disorder, 13. Cranial neuralgias and central causes of facial pain, 14. Other headache, cranial neuralgia, central or primary facial pain; **n, number of patients.

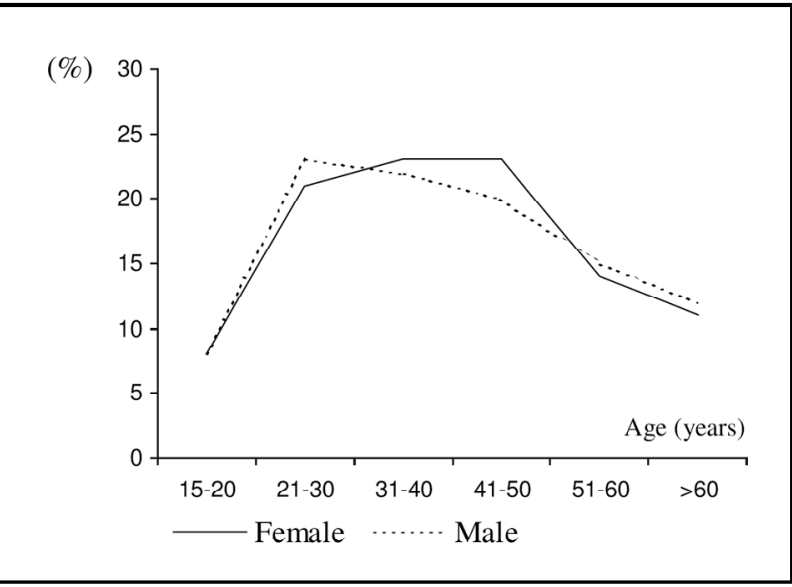

Figure. Headache prevalence according to age and sex. 
The headache diagnosis given for each patient a re shown in Table 2 and were preferably characterized according to its main group (i.e., migraine, tension-type). Among 121 patients in the group of "other primary headaches" (Table 2) 24 had the diagnosis of hypnic headache syndrome. Since we considered only the headaches that led to medical attendance (primary complaint), the number of patients seen equaled the number of diagnoses.

Age and sex-specific prevalence of all headaches a re presented on Figure. The peak prevalence was between ages 21 to 50 either for women or men.

\section{DISCUSSION}

We have found few epidemiological data regard ing primary or secondary headaches in clinic-based studies, mainly in developing countries ${ }^{5-12}$. Thus, this su rvey brings relevant information on the features of a specialized tertiary headache service in Brazil, contrasting epidemiological data from community or out-hospital headache suffe rers from North America and Europe. It is also one of the first epidemiological studies that used the ICHD-II (2004) for diagnostic criteria purposes.

As a general rule, women tended to seek for health care attention much more than men in our sample. This is in agreement with a population-based study and according to the same author the over- re p resentation of women may be attributed to the female hormone's influence and the fact that they seek much more for health-care attention than men ${ }^{14}$. With regard to race we also noted that the prevalence of white patients was higher than non-whites. This is a controversial data. In an epidemiologic study of migraine symptoms in young women no significant differences were found when comparing race prevalence ${ }^{15}$. In Brazil this is a much more controversial issue since the difference between white and nonwhite is closely related to historical influences, having the non-white usually lower social and educational level that can make them take longer to seek for help. Both women and men mean of age were similar, around 40 years old, the average peak prevalence being for both migraine and tension-type headache according to Lipton ${ }^{3}$ and Schwartz ${ }^{6}$, the main diagnoses in our population.

Socioeconomic status may be estimated according to years of school instruction. The majority of our patients had no more than 8 years of school instruc- tion, which probably corresponds to our hospital setting characteristic, that is, a public hospital, which in Brazil accommodates low-income populations since high-income groups seek for Health Managed Organization's hospitals. Population-based studies in North America indicate that migraine prevalence is inversely related to socioeconomic status ${ }^{16}$, which was not the same as in Europe. Thus, due to our population selection bias, it is hard to come to a conclusion.

Pain duration was incredibly high in our population. Approximately $16 \%$ of the headache sufferers came with less than 1 year of pain duration; about $85 \%$ suffe red for more than 1 year before seeking for health care, and most of them more than 6 years. Generally men attended later than women. It is known that in North America only $16 \%$ of the headache suffe rers seek for Headache specialty care and that almost $50 \%$ are current consulters ${ }^{6}$. This is of large economical impact since patients with long-lasting headaches usually become undert reated or even underdiagnosed. These data also show that patients are lately referred to a Headache specialty care.

Migraine was the main diagnose that lead patients to our headache clinic, no matter it was episodic or chronic daily headache. In population-based studies the prevalence of migraine is lesser than tension-type headache, but due to selection bias in clinic-based studies, patients in such series tend to have more severe, more frequent, or more complex types of headache than in the general population ${ }^{1-4}$.

It is also noteworthy from data shown on Table 2 that primary headaches accounted for the main diagnoses in our series, in spite of secondary headaches and cranial neuralgia. This might be due to the selection bias as mentioned above, but it is important to notice that our hospital also has pain-clinics that also accommodate these patients and were not taken into account. Data from other clinic-based study confirm s that observation ${ }^{17}$.

Clinic-based studies might help in providing information about the patients attending a specific headache unit. From this point of view, treatment strategies and public health planning can be made.

The prevalence of migraneurs in our clinic show how scarce is the search for help from tension-type headache sufferers. It is also noteworthy the length of time patients spent until reaching specialized headache attendance.

In conclusion, more clinic-based studies should be 


\section{done with the purpose of comparing these data with population-based studies so that specific health care strategies may be outlined for these distinct popu- lations' settings.}

\section{REFERENCES}

1. Rasmussen BK, Jensen R, Schroll M, Olessen J. Epidemiology of headache in a general population: prevalence study. J Clin Epidemiol 1991;44:1147-1157.

2. Rasmussen BK. Epidemiology of headache. Cephalalgia 1995;15:45-68.

3. Lipton R, Stewart WF. Migraine in the United States: a review of epidemiology and health care use. Neurology 1993;43(Suppl 3):S6-S10.

4. Lipton R, Diamond S, Reed M, et al. Migraine diagnosis and treatment: results from the American Migraine Study II. Headache 2001;41:638-645.

5. Smith TR. Epidemiology and impact of headache: an overview. Prim Care Clin Office Pract 2004;31:237-241.

6. Schwartz BS, Stewart WF, Simon D, Lipton R. JAMA 1998;279:381-383.

7. Quesada-Vázquez AJ, Traba-Tamayo ER. Epidemiología de la cefalea en una consulta de medicina interna. Rev Neurol 2003;36:597-598.

8. Bigal ME, Bigal JOM, Bordini CA, Speciali JG. Prevalence and costs of headaches for the public health system in a town in the interior of the State of Sao Paulo. Arq Neuropsiquiatr 2001;59:504-511.
9. Bigal ME, Bordini CA, Speciali JG. Etiology and distribution of headaches in two Brazilian primary care units. Headache 2000;40:248-251.

10. Bigal ME, Bordini CA, Speciali JG. Headache in an emergency room. Sao Paulo Medical J 2000;3:74-79.

11. Domingues RB, Kuster GW, Dutra LA, Santos JG. Headache epidemiology in Vitoria, Espirito Santo. Arq Neuropsiquiatr 2004;62:588-591.

12. Costa MZ, Soares CB, Heinisch LM, Heinisch RH. Frequency of headache in the medical students of Santa Catarina's Federal University. Headache 2000;40:740-744.

13. Sanvito WL, Monzillo PH, Peres MF, et al. The epidemiology of migraine in medical students. Headache 1996;36:316-319.

14. Rasmussen BK. Migraine and tension-type headache in a general population: precipitating factors, female hormones, sleep pattern and relation to lifestyle. Pain 1993;53:65-72.

15. Markush RE, Karp HR, Heyman A, O'Fallon WM. Epidemiologic study of migraine symptoms in young women. Neurology 1975;25:430-435.

16. Mannix LK. Epidemiology and impact of primary headache disorders. Headache 2001;85:887-895.

17. Dowson AJ. Analysis of the patients attending a specialist UK Headache Clinic over a 3-year period. Headache 2003;43:14-18.

18. Subcomitê de Classificação das Cefaléias da Sociedade Internacional de Cefaléias. Classificação Internacional das Cefaléias, 2a Edição (ICHDII). Tradução da Sociedade Brasileira de Cefaléia. São Paulo: Segmento Farma Editores, 2004. 